\title{
FEATURE Cattle, conservation, and carbon in the western Great Plains
}

John S. Sanderson, Curtis Beutler, Joel R. Brown, Indy Burke, Teresa Chapman, Richard T. Conant, Justin D. Derner, Mark Easter, Samuel D. Fuhlendorf, Grady Grissom, Jeffrey E. Herrick, Daniel Liptzin, Jack A. Morgan, Rachel Murph, Chris Pague, Imtiaz Rangwala, David Ray, Renee Rondeau, Terri Schulz, and Tim Sullivan

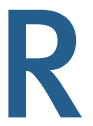

angelands have garnered attention for their potential to store carbon (C) and have been included in France's 4 per 1,000 initiative (Minasny et al. 2017), methods for maintaining or increasing $\mathrm{C}$ in grassland soils (American Carbon Registry 2013; Verified Carbon Standard 2017), and portfolios of natural climate solutions (Griscom et al. 2017; Fargione et al. 2018). Rangelands are used to graze livestock, and they provide habitat for species, C storage, and other environmental benefits. Rangelands cover nearly half the world's terrestrial surface and store up to $20 \%$ of the global soil organic C (Conant 2012). However, rangelands are being converted to other land uses such as cropland (Lark et al. 2015), housing, industry, transportation, and energy production. Approximately 600,000 ha $\left(1.48 \times 10^{6} \mathrm{ac}\right)$ of US rangelands were converted to other uses between 2007 and 2012, and another 360,000 ha $\left(0.89 \times 10^{6} \mathrm{ac}\right)$ between 2012 and 2015 (USDA 2018). Despite the increasing attention being given to soil C, some reports urging soil $\mathrm{C}$ management do not mention avoiding conversion (Lal 2019). We suggest that avoiding the loss of rangelands should be given more attention than it currently receives because it offers a well-established approach to retaining soil $\mathrm{C}$ along with the other ecosystems services that rangelands provide.

Managing rangelands for livestock production in semiarid environments, on the other hand, is challenging because of low average annual precipitation and high year-to-year variability in weather. Managing livestock to achieve other conservation goals, like C storage, is even more complex because of the ever-changing economic conditions and policies that may be at odds with desired societal outcomes. Furthermore, land management decisions are made more difficult by debates in the global scientific literature, popular press, and social media that have obscured areas of broad agreement. Recommendations for win-win-win strategies for cattle, conservation, and C are needed for ranchers, federal and state land managers, and policy makers to integrate multiple goals in these ecosystems.

Our objectives with this paper are to (1) summarize the state of knowledge of the major controls on soil C stocks and fluxes in the western Great Plains of the United States (figure 1); (2) describe synergistic opportunities for cattle, conservation, and $\mathrm{C}$ in this region; and (3) describe the characteristics of the research needed to advance the opportunities. We focus on this region because nearly all of its $\mathrm{C}$ stocks are belowground (Burke et al. 1997); extensive research on the region has been published; and the region's climate, vegetation, and land use have similarities to semiarid rangeland ecosystems throughout the world, including Mongolia, South Africa, and Argentina. Moreover, massive C fluxes have occurred in this region over the past century, most notably the 1930s Dust Bowl (Follett 2009).

\section{CONTROLS OVER CARBON IN}

\section{SEMIARID RANGELANDS}

In semiarid rangelands, climate and soil texture are major, long-term (decades to centuries) determinants of soil $\mathrm{C}$ stocks (total organic C). In the short term (within year to several years), weather can dominate short-term fluxes (changes in stocks), irrespective of management.

Efforts to change soil C stocks through policy and management must be based on a comprehensive understanding of the $\mathrm{C}$ cycle. In semiarid grasslands, like the Great Plains, $80 \%$ to $90 \%$ of the ecosystem's organic C is in the soil (Burke et al. 1997; Derner et al. 2006). Most ( 85\%) soil organic $\mathrm{C}$ is highly stable unless disturbed, having accumulated over centuries as a function of climate, vegetation, topography, and age of the soil (figure 2). The soil organic C stock represents the long-term balance between the annual flow of $\mathrm{C}$ into soils from photosynthesis and the respira-
John S. Sanderson is the director of the Center for Collaborative Conservation, Colorado State University, Fort Collins Colorado. Curtis Beutler is a professional research assistant for the Watershed Function SFA-Lawrence Berkeley National Laboratory, Crested Butte, Colorado. Joel R. Brown is a rangeland ecologist with the USDA Natural Resources Conservation Service (NRCS) at the USDA Agricultural Research Service (ARS) Jornada Experimental Range, Las Cruces, New Mexico. Indy Burke is dean of the Yale School of Forestry and Environmental Studies, Yale University, New Haven, Connecticut. Teresa Chapman is GIS manager at The Nature Conservancy, Boulder, Colorado. Richard T. Conant is an ecosystem ecologist at the Natural Resource Ecology Laboratory, Colorado State University, Fort Collins, Colorado. Justin D. Derner is a rangeland scientist at the USDA ARS Rangeland Resources and Systems Research Unit, Cheyenne, Wyoming/Fort Collins, Colorado. Mark Easter is a senior research associate at the Natural Resource Ecology Laboratory, Colorado State University, Fort Collins, Colorado. Samuel D. Fuhlendorf is a professor in the Department of Natural Resource Ecology and Management, Oklahoma State University, Stillwater, Oklahoma. Grady Grissom is a rancher at Rancho Largo Cattle Co., Fowler, Colorado. Jeffrey E. Herrick is a soil scientist with the USDA NRCS at the USDA ARS Jornada Experimental Range, Las Cruces, New Mexico. Daniel Liptzin is a project scientist at the Soil Health Institute, Denver, Colorado. Jack A. Morgan is a retired plant physiologist at the USDA ARS Rangeland Resources and Systems Research Unit, Cheyenne, Wyoming/Fort Collins, Colorado. Rachel Murph is a state rangeland management specialist at the USDA NRCS Colorado State Office, Denver, Colorado. Chris Pague is senior conservation ecologist at The Nature Conservancy, Boulder, Colorado. Imtiaz Rangwala is a research scientist at the Cooperative Institute for Research in Environmental Sciences, University of Colorado and Physical Sciences Division, National Oceanic and Atmospheric Administration, Boulder, Colorado, and Department of Interior North Central Climate Adaptation Science Center, Boulder, Colorado. David Ray is chief conservation officer at the Lowcountry Land Trust, Charleston, South Carolina. Renee Rondeau is an ecologist at the Colorado Natural Heritage Program, Colorado State University, Fort Collins, Colorado. Terri Schulz is senior conservation ecologist at The Nature Conservancy, Boulder, Colorado. Tim Sullivan is the North America climate director at The Nature Conservancy, Steamboat Springs, Colorado. 
tion of carbon dioxide $\left(\mathrm{CO}_{2}\right)$ back to the atmosphere by microorganisms.

Soil organic C develops from a wide range of plant-derived compounds that are processed by soil organisms into $\mathrm{CO}_{2}$ and an array of organic products that are stabilized by chemical or physical processes (Grandy and Neff 2008). The C released into the atmosphere through soil respiration comes from a small subset of the soil organic matter (Trumbore 2000). Thus, soil C consists of a diverse stew of organic materials, but only $\sim 15 \%$ of rangeland soil C is "active," increasing or decreasing over months or years depending on the balance between photosynthesis and decomposition. The remainder is protected from conversion to $\mathrm{CO}_{2}$ because the $\mathrm{C}$ is either in a molecular form that is hard to break down or it is physically protected within soil aggregates and thereby inaccessible to bacteria.

In a given location, the soil $\mathrm{C}$ stock is generally predictable as a function of climate and soil texture, which only change over long time scales and are not subject to management actions (Burke et al. 1989) (figure 2). However, small changes in soil $\mathrm{C}$ do occur from year to year, primarily as a function of water availability (McSherry and Ritchie 2013). During wet years, soil C stocks can increase because plant growth exceeds decomposition (Schuman et al. 1999). Wet conditions also accelerate decomposition and loss of soil C, but those losses are more than offset by higher plant production. Conversely, drought can decrease plant growth below the rate of decomposition, resulting in soil $\mathrm{C}$ losses, irrespective of management (Morgan et al. 2016).

Soil Carbon Response to Management. The potential to increase soil $\mathrm{C}$ stocks in native semiarid rangelands due to rangeland management is small on a per unit area basis. At both the regional and global scales, effects of grazing on soil $\mathrm{C}$ are highly variable (Milchunas and Lauenroth 1993; McSherry and Ritchie 2013). Conant et al. (2017) synthesized 50 studies that reported soil $\mathrm{C}$ responses to improved grazing in grasslands across the globe (including but not restricted to semiarid rangelands). These studies reported a range of response from greater than $50 \% \mathrm{C}$ loss to nearly $200 \% \mathrm{C}$ gain. The mean soil C

\section{Figure 1}

Western Great Plains.

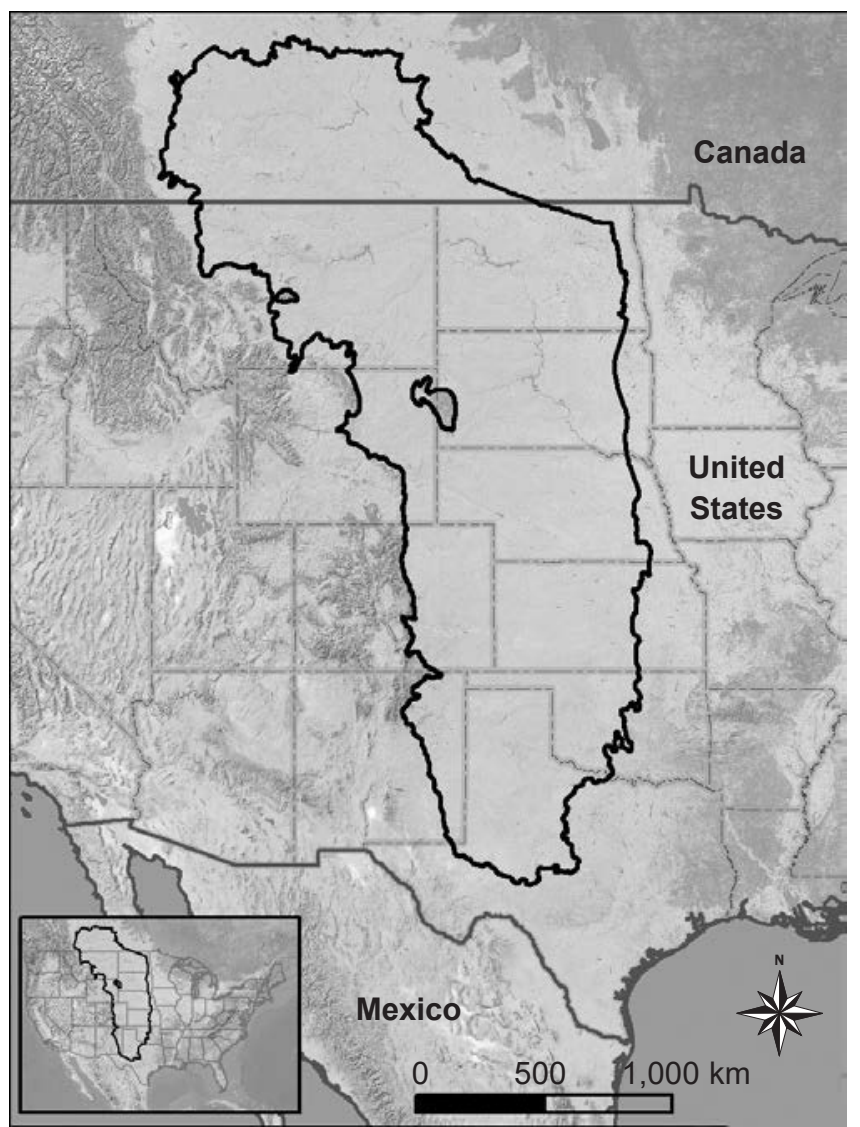

response was a 10\% increase, although 51\% of the studies reported a decrease.

We synthesized published data from western Great Plains rangelands on changes in soil organic $\mathrm{C}$ in grazed relative to control treatments (ungrazed pastures). Consistent with prior reviews of the literature in the region (Derner and Schuman 2007), we found a negative relationship between the effect of grazing and precipitation after at least a decade of grazing. For every $100 \mathrm{~mm}$ (4 in) decrease in precipitation, there was a $4.5 \%$ increase in soil C in the grazing treatment compared to the control (figure 3). Based on a linear regression, the predicted switch from a positive to a negative effect of grazing on soil C occurred at $538 \mathrm{~mm}$ (21 in) of precipitation. Thirteen of the 17 experimental grazing treatments at sites with less than $538 \mathrm{~mm}$ of precipitation showed a positive effect of grazing on soil $\mathrm{C}$ with an average increase of soil $\mathrm{C}$ of $7 \%$.
Several other syntheses have shown, on average, an increase in soil $\mathrm{C}$ with improved grazing (Wang et al. 2016 ), while other studies have found no effect of grazing on soil C (Derner et al. 2019). Where grazing has increased soil $\mathrm{C}$, the rate of increase has typically been low (0.05 to $0.50 \mathrm{Mg} \mathrm{C} \mathrm{ha}{ }^{-1} \mathrm{y}^{-1}$ [0.02 to 0.22 tn $\mathrm{C} \mathrm{ac}^{-1} \mathrm{yr}^{-1}$ ] [Schuman et al. 2002; Henderson et al. 2015]), although higher sequestration rates have been reported on highly degraded lands in areas with higher annual precipitation (e.g., $3 \mathrm{Mg} \mathrm{C} \mathrm{ha}^{-1} \mathrm{y}^{-1}$ [1.3 tn $\mathrm{C} \mathrm{ac}^{-1} \mathrm{yr}^{-1}$ ] [Teague et al. 2016]).

Projected Trends. In western Great Plains rangelands, observed trends and model projections indicate significantly warmer conditions and higher atmospheric $\mathrm{CO}_{2}$ concentrations by the mid-twenty-first century, which will cause hydrological and ecological changes. Uncertainty about these changes limits our ability to forecast impacts on soil C stocks. 


\section{Figure 2}

(a) An example of the distribution of carbon (C) stocks in the semiarid, shortgrass steppe ecosystem to $1 \mathrm{~m}$ depth, modified from Burke et al. (1997). Values are in kilograms per hectare; values in parentheses are turnover times of component pools. (b) Major factors that affect soil C.

(a)

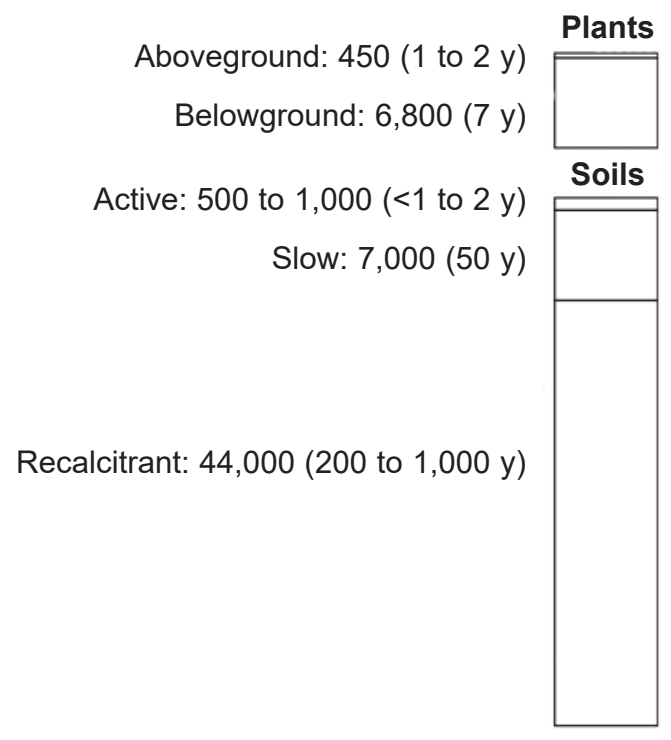

(b)

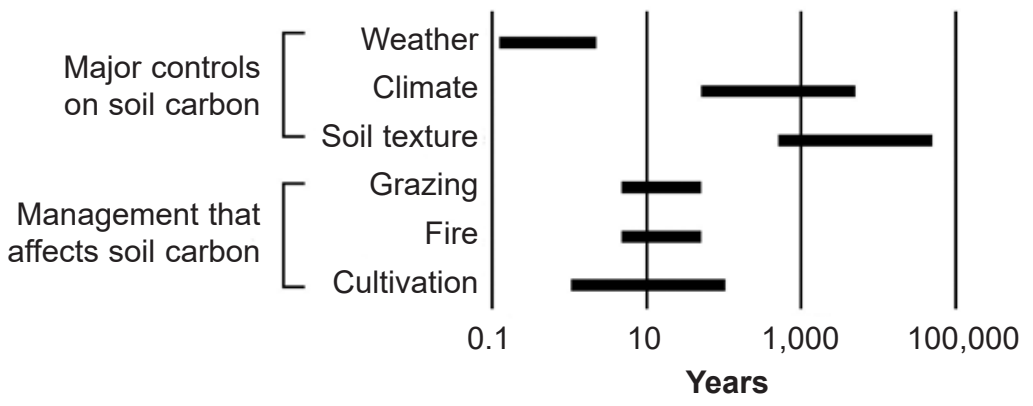

Current and projected directional climate trends during the twenty-first century for the western Great Plains include the following: (1) increasing land and air temperatures; (2) longer growing seasons; (3) change in soil moisture (figure 4), including frequency and severity of soil moisture deficits later in the growing season; (4) more rainfall than snowfall; and (5) increasing extreme weather including heat waves, droughts, and flooding (Walsh et al. 2014). Directional changes in total precipitation are less certain; models generally project increases in precipitation in the northern Great Plains and decreases for the southern Great Plains (Walsh et al. 2014).

Higher minimum annual temperatures, elevated atmospheric $\mathrm{CO}_{2}$, and longer growing seasons are expected to
C uptake (Hufkens et al. 2016; Mueller et al. 2016), although uncertainty is high.

Plant species composition of western Great Plains rangelands is certain to respond to global changes, with possible implications for ecosystem services, including forage production and soil $\mathrm{C}$ stocks. For example, elevated $\mathrm{CO}_{2}$ levels favor perennial $\mathrm{C}_{3}$ (cool season) forage grasses at the expense of the resilient and drought resistant $\mathrm{C}_{4}$ (warm season) perennial grasses (Mueller et al. 2016). This change could lead to increased forage productivity, but could also lead to lower soil water availability (Tietjen et al. 2017). Derner et al. (2019) found that C stocks did not change even after significant vegetation change (Augustine et al. 2017), yet uncertainty remains about soil $\mathrm{C}$ changes following vegetation changes due to variable and inadequate understanding of C allocation patterns among dominant grasses (Derner and Schuman 2007).

Changing Vegetation in Great Plains Rangeland. Altered fire regimes have contributed to the invasion of woody plants into western Great Plains rangelands, which has increased aboveground $\mathrm{C}$ stocks while diminishing livestock productivity and other conservation values.

Prior to European settlement in the western Great Plains, fire and native grazers-and the interaction between the two-were primary influences on vegetation patterns, and woody plants were largely confined to rocky, north-facing slopes and canyon walls (Fuhlendorf et al. 2011). After European settlement, fire suppression and cattle grazing that reduced fuel loads altered fire regimes at numerous spatial and temporal scales. As a result, woody plants-especially Juniperus spp.invaded portions of the western Great Plains with lower moisture stress (mostly eastern and wetter areas). Invasion by the woody plants increases aboveground C storage (Fuhlendorf et al. 2011), but this $\mathrm{C}$ is highly susceptible to rapid loss from fires or brush management that removes the trees. Also, woody plant invasion diminishes ecosystem services associated with treeless ecosystems, such as habitat for grassland birds (Rosenstock and Van Riper, III 2001). 


\section{THE PATH FORWARD: RECOMMENDATIONS}

Preserve Rangelands to Maintain Carbon

Stocks. Keeping rangelands intact is the single most important action for maximizing soil C stocks in western Great Plains rangelands. Rangeland soils lose large amounts of $\mathrm{C}$ quickly when severely degraded or converted to other land uses, whereas large increases in soil $\mathrm{C}$ are difficult to achieve. The largest losses occur when the amount of recalcitrant, slow cycling soil C (figure 2) is reduced through direct human actions that stimulate decomposition (Burke et al. 1997). The effect of plowing on soil $\mathrm{C}$ in native rangelands is highly predictable: soils quickly lose $50 \%$ or more of C stocks (Guo and Gifford 2002) because decomposition and erosion speed up following the breakdown of soil structure and aggregates. This soil C-up to $25 \mathrm{Mg}$ $\mathrm{C} \mathrm{ha}^{-1}$ (11 tn $\mathrm{C} \mathrm{ac}^{-1}$ ) or more, depending on soil type-takes many decades or centuries to recover (Ihori et al. 1995; Burke et al. 1995). In contrast, the effects of grazing management on soil C are typically much smaller and less predictable (McSherry and Ritchie 2013).

Restore Cultivated and Degraded Lands. While keeping rangelands intact reduces the loss of soil $\mathrm{C}$, the greatest potential for increasing soil $\mathrm{C}$ is in previously cultivated and degraded lands. Management actions have the potential to increase soil C stocks in semiarid environments on formerly cultivated and degraded lands. Restoration of perennial vegetation can result in increased soil $\mathrm{C}$ in rangelands (Robles and Burke 1998; Milchunas and Vandever 2013), particularly the labile pools of soil organic matter, and management of livestock grazing is likely a critical factor governing restoration (Fuhlendorf et al. 2002). Although a vast area of formerly cultivated land in the western Great Plains has been placed in the Conservation Reserve Program where tillage is halted and perennial vegetation is established, disincentives for grazing on these lands create conditions where these lands are not managed to optimize C sequestration.

Climate projections that indicate stable or improving soil moisture conditions in

\section{Figure 3}

Soil organic carbon (C) after grazing treatment as a percentage of control versus mean annual precipitation. The line indicates the best-fit trend from a linear regression $\left(R^{2}=0.33, p<0.006\right)$. Synthesized from research in the Great Plains (Frank et al. 1995; Manley et al. 1995; Henderson 2000; Reeder et al. 2004; Derner et al. 2006; Ingram et al. 2008; Teague et al. 2011).

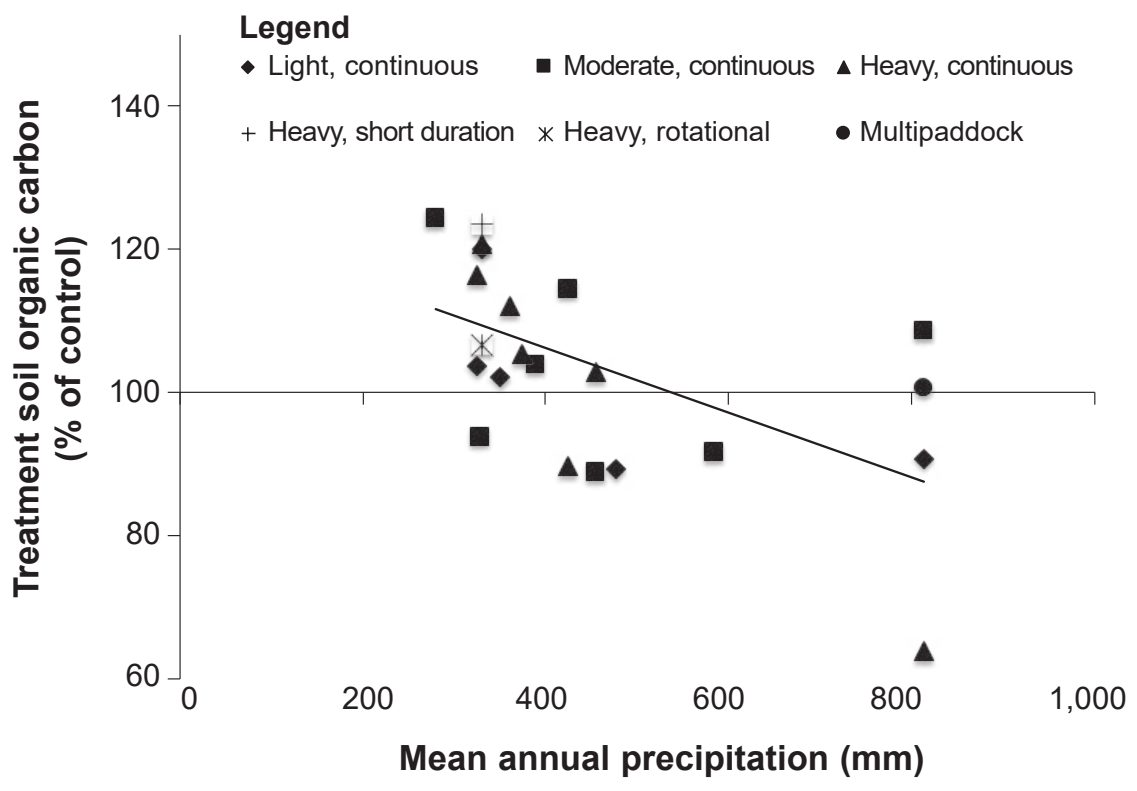

the northern portion of the Great Plains (Walsh et al. 2014) suggest this region will have greater opportunities for restoration of formerly cultivated lands and livestock grazing management consistent with increasing soil C (Walthall et al. 2012). In contrast, increasing heat and drought stress projected for the southern Great Plains indicate a greater need to incorporate strategies in drought management plans (Derner and Augustine 2016) to avoid excessive soil C losses during drought.

Practice Adaptive Livestock Management. Adjusting livestock numbers in response to fluctuating forage production conditions is necessary to realize any potential for longterm soil C stock increases. Throughout the Great Plains, experimental research and practical application has shown that when forage consumption exceeds plant production, roots grow less (Crider 1955), and consequently, soil $\mathrm{C}$ inputs decrease (Morgan et al. 2016). Inappropriate season of use and heavy stocking can shift plant species composition, reduce the effects of rainfall, and lower annual plant production (Milchunas et al. 1994), leading to reductions in soil C stocks over decades (Derner et al. 2006). Ultimately, excessive live- stock grazing increases the risk of erosion, thereby limiting the long-term capacity to store and retain soil $\mathrm{C}$.

Drought conditions lead to soil C losses regardless of grazing management (Morgan et al. 2016), with losses greater for heavy stocking compared to moderately stocked or ungrazed sites. Rangeland management should prioritize reduction of C losses by employing adaptive management to adjust livestock numbers quickly to forage availability under changing weather and climatic conditions (Briske et al. 2011), including drought (Derner and Augustine 2016). Here, the priority for long-term rangeland sustainability and maintenance of soil $\mathrm{C}$ is to ensure sufficient plant cover and litter to prevent soil loss by wind and/ or water erosion (Briske et al. 2011; Teague et al. 2011).

Across the western Great Plains, soils, vegetation, and climate vary, e.g., the relative abundance of $\mathrm{C}_{3}$ versus $\mathrm{C}_{4}$ plants is generally greater farther north, and this variability affects plant productivity. Regardless of this variability, principles that underpin successful conservation of rangelands are the same: (1) goals for livestock production and ecosystem 
health - including soil C-will be attained only if season of use and amount of forage consumption are planned with goals in mind, (2) monitoring should be conducted to determine if goals are being met, and (3) management must be adapted over time in response to monitoring results and changing conditions.

\section{CONCLUSIONS}

Semiarid rangelands in the western Great Plains, and throughout the world, have important potential to contribute to global food security, provide wildlife habitat and other ecosystem services, and sustain rural economies and ranching heritage (Erb et al. 2016). Recent work has demonstrated the importance of rangelands to the management of soil $\mathrm{C}$ stocks across the globe (Conant et al. 2017). Decades of research on grazing management practices offer solid evidence that basic ecological principles applied in an adaptive management framework can increase resilience of rangelands resulting in sustainable production (Briske et al. 2011) and lead to potential long-term maintenance or modest increases in soil $\mathrm{C}$ stocks. Ensuring that native rangelands are not converted to other land uses is paramount to ensuring ecological, social, and economic success of twenty-first century ranches, and keeping rangelands intact is the most important action for maximizing $\mathrm{C}$ stocks. Restoring cultivated lands to perennial native vegetation that is managed under sustainable practices-and ensuring that those lands remain uncultivated-is also an important strategy to maintain or possibly increase soil C stocks.

Numerous incentives exist for keeping rangelands intact. The Agricultural Improvement Act of 2018 (commonly called the "Farm Bill") carries forward and expands voluntary programs where producers are paid for actions that, while not explicitly targeting $\mathrm{C}$, may retain $\mathrm{C}$ stocks or increase $\mathrm{C}$ sequestration. For example, the cap on Conservation Reserve Program enrollment will increase to 10.9 Mha (2.7 $\times 10^{7} \mathrm{ac}$ ) by 2023 ; rules around management of Conservation Reserve Program lands allow more flexibility around grazing, which could decrease pressure to disenroll from the program; and the

\section{Figure 4}

Mean change in soil moisture compared to 1971 to 2000, as projected for the middle of this century (2041 to 2070) and late this century (2071 to 2100) under (a) a higher and (b) lower emissions scenario. Scenarios are from Nakicenovic and Swart (2000). Source: Walsh et al. 2014.

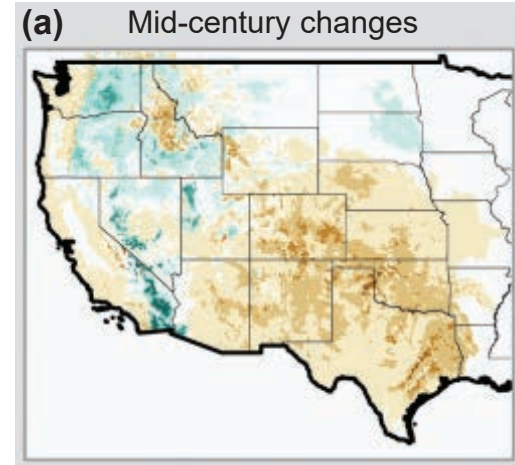

(b) Mid-century changes

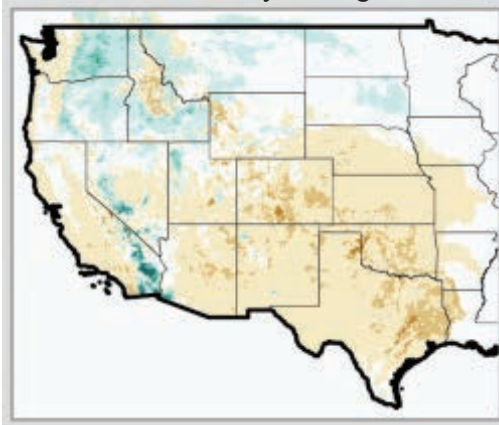

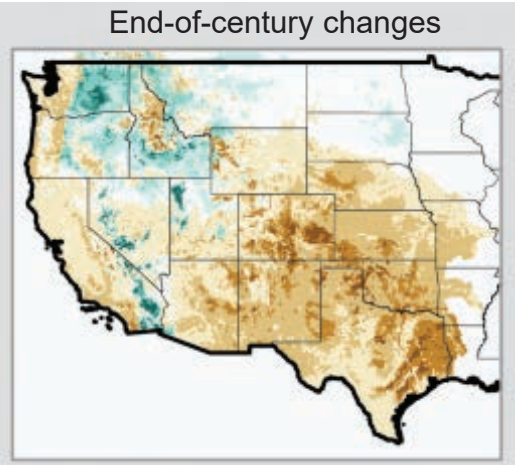

End-of-century changes

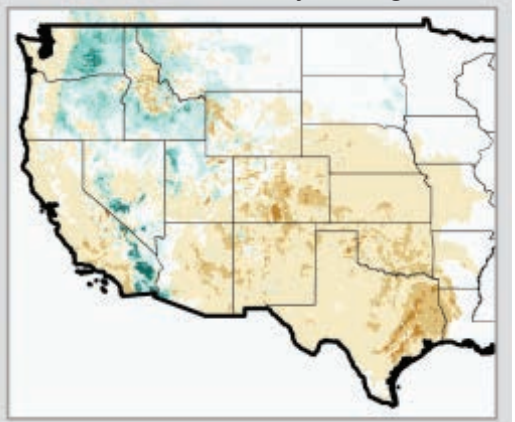

Change (\%)

\begin{tabular}{ll|lll|l|l|l|l|l}
$\longleftarrow$ & & & & & & & & \\
-15 & -10 & -5 & -1 & 1 & 5 & 10 & 15
\end{tabular}

"Sodsaver" provision is stronger, further disincentivizing conversion of native land in the northern Great Plains. Through C markets, landowners can be directly compensated for avoided conversion of rangelands (Verified Carbon Standard 2017), although overall uptake has been slow. Among nongovernmental organizations, the Audubon Society (2017) and The Nature Conservancy (2019) provide training and other incentives to keep rangelands intact. Despite these programs, rangelands continue to be converted to other uses, so maintaining $\mathrm{C}$ stocks could require new or enhanced incentives to avoid conversion.

Although the potential to increase soil C stocks in semiarid regions due to rangeland management is modest per unit area compared to avoiding conversion of native lands or restoring native perenni- als to formerly cultivated lands, the many ecosystem services-including C storage - of rangelands provide ample reasons to work for the success of ranching. On twenty-first century ranches, success for cattle, conservation, and $\mathrm{C}$ is dependent on setting operation-specific goals for cattle production, ecosystem conservation, and $\mathrm{C}$ stocks, with use of adaptive grazing management over space and time in response to the many dynamic factors (e.g., precipitation and market forces) that influence decision-making (FernándezGiménez et al. 2019). Like all land use and management planning, the process should begin with an evaluation of the sustainable potential of each pasture or watershed (Herrick et al. 2016), taking advantage of the extensive resources already available for the United States, such as ecological site descriptions and associated state-and- 
transition models. Monitoring is essential to determine progress toward goals and to modify management if needed.

Integrating the complexities of a changing climate, socioecological systems, and day-to-day ranching operations requires a new approach to both research and policy. Research must include an enhanced understanding of the impacts of directional climate changes (e.g., increasing atmospheric $\mathrm{CO}_{2}$, precipitation, and growing season length) on the interactions among grazing management and ecosystem responses (e.g., plant growth and soil C change). Policy to support sustainability in rangelands will also have to account for the complexity of managing for economic stability in a highly variable environment (Irisarri et al. 2019). Creative win-win-win strategies for cattle, conservation, and $\mathrm{C}$ should emphasize management-science partnerships that are collaborative and transdisciplinary, embrace complex social-ecological systems, and are conducted at relevant scales (Roche et al. 2015; Wilmer et al. 2018). These collaborative efforts need to involve ranchers, researchers, and policy makers working together to improve decision-making for a twenty-first century ranch that produces livestock, conserves native species, stores $\mathrm{C}$, and provides other goods and services desired by society.

\section{REFERENCES}

American Carbon Registry. 2013. Methodology for avoided conversion of grasslands and shrublands to crop production. Arlington,VA:American Carbon Registry. https://americancarbonregistry.org/ carbon-accounting/standards-methodologies/ methodology-for-avoided-conversion-of-grasslands-and-shrublands-to-crop-production/ acr-acogs-methodology_v1-0_final.pdf.

Audubon Society. 2017. Conservation Ranching. New York: National Audubon Society. https:// www.audubon.org/sites/default/files/conservation_ranching_protocols_sep2017.pdf.

Augustine, D.J., J.D. Derner, D.G. Milchunas, D. Blumenthal, and L.M. Porensky. 2017. Grazing moderates increases in $\mathrm{C}_{3}$ grass abundance over seven decades across a soil texture gradient in shortgrass steppe. Journal of Vegetation Science 28(3):562-572.

Briske, D.D., J.D. Derner, D.G. Milchunas, and K.W. Tate. 2011. An evidence-based assessment of prescribed grazing practices in conservation benefits of rangeland practices: Assessment, recommendations, and knowledge gaps. In Conservation Benefits of Rangeland Practices: Assessment, recommendations and knowledge gaps, ed. D.D. Briske, 21-74. Washington, DC: USDA Natural Resources Conservation Service.

Burke, I.C., W.K. Lauenroth, and D.P. Coffin. 1995. Soil organic matter recovery in semiarid grasslands: Implications for the Conservation Reserve Program. Ecological Applications 5(3):793-801.

Burke, I.C., W.K. Lauenroth, and D.G. Milchunas. 1997. Biogeochemistry of managed grasslands in central North America. In Soil Organic Matter in Temperate Agroecosystems: Long-term experiments in North America, eds. E.A. Paul, K.H. Paustian, E.T. Elliot, and C.V. Cole, p. 432. New York, NY: CRC Press.

Burke, I.C., C.M.Yonker, W.J. Parton, C.V. Cole, D.S. Schimel, and K. Flach. 1989. Texture, climate, and cultivation effects on soil organic matter content in US grassland soils. Soil Science Society of America Journal 53(3):800-805.

Conant, R. 2012. Grassland soil organic carbon stocks: Status, opportunities, vulnerability. In Recarbonization of the Biosphere, eds. R. Lal, K. Lorenz, R.F. Hüttl, B.U. Schneider, and J. von Braun. Dordrecht: Springer.

Conant, R.T., C.E.P. Cerri, B.B. Osborne, and K. Paustian. 2017. Grassland management impacts on soil carbon stocks: A new synthesis. Ecological Applications 27(2):662-668.

Crider, F. 1955. Root-growth stoppage resulting from defoliation of grass. Washington, DC: USDA.

Derner, J.D., and D.J. Augustine. 2016. Adaptive management for drought on rangelands. Rangelands 38(4):211-215.

Derner, J.D., D.J. Augustine, and D.A. Frank. 2019. Does grazing matter for soil organic carbon sequestration in the western North American Great Plains? Ecosystems 22(5):1088-1094.

Derner, J.D., T.W. Boutton, and D.D. Briske. 2006. Grazing and ecosystem carbon storage in the North American Great Plains. Plant and Soil 280(1-2):77-90.

Derner, J.D., and G.E. Schuman. 2007. Carbon sequestration and rangelands: A synthesis of land management and precipitation effects. Journal of Soil and Water Conservation 62(2):77-85.

Erb, K.-H., C. Lauk, T. Kastner, A. Mayer, M.C. Theurl, and H. Haberl. 2016. Exploring the biophysical option space for feeding the world without deforestation. Nature Communications 7(April 19, 2016):11382.

Fargione, J.E., S. Bassett, T. Boucher, S.D. Bridgham, R.T. Conant, S.C. Cook-Patton, P.W. Ellis, A.
Falcucci, J.W. Fourqurean, T. Gopalakrishna, H. Gu, B. Henderson, M.D. Hurteau, K.D. Kroeger, T. Kroeger, T. J. Lark, S.M. Leavitt, G. Lomax, R.I. McDonald, J.P. Megonigal, D.A. Miteva, C.J. Richardson, J. Sanderman, D. Shoch, S.A. Spawn, J. W. Veldman, C.A. Williams, P.B. Woodbury, C. Zganjar, M. Baranski, P. Elias, R.A. Houghton, E. Landis, E. McGlynn, W.H. Schlesinger, J.V. Siikamaki, A.E. Sutton-Grier, and B.W. Griscom. 2018. Natural climate solutions for the United States. Science Advances 4(11): eaat1869.

Fernández-Giménez, M., D. Augustine, L. Porensky, H. Wilmer, J. Derner, D. Briske, and M. Stewart. 2019. Complexity fosters learning in collaborative adaptive management. Ecology and Society 24(2)29.

Follett, R.F. 2009. US agriculture's relationship to soil carbon. Journal of Soil and Water Conservation 64(6):159A-165A, 10.2489/jswc.64.6.159A.

Frank,A.B., D.L.Tanaka, L. Hofmann, and R.F. Follett. 1995. Soil carbon and nitrogen of northern Great Plains grasslands as influenced by longterm grazing. Journal of Range Management 48(5):470-474.

Fuhlendorf, S.D., R.F. Limb, D.M. Engle, and R.F. Miller. 2011. Assessment of prescribed fire as a conservation practice. In Conservation Benefits of Rangeland Practices: Assessment, recommendations and knowledge gaps, ed. D.D. Briske, 75-104. Washington, DC: USDA Natural Resources Conservation Service.

Fuhlendorf, S.D., H. Zhang, Tim. R. Tunnell, D.M. Engle, and A.F. Cross. 2002. Effects of grazing on restoration of southern mixed prairie soils. Restoration Ecology 10(2):401-407.

Grandy, A.S., and J.C. Neff. 2008. Molecular C dynamics downstream: The biochemical decomposition sequence and its impact on soil organic matter structure and function. Science of the Total Environment 404(2):297-307.

Griscom, B.W., J. Adams, P.W. Ellis, R.A. Houghton, G. Lomax, D.A. Miteva, W.H. Schlesinger, D. Shoch, J.V. Siikamäki, P. Smith, P. Woodbury, C. Zganjar,A. Blackman, J. Campari, R.T. Conant, C. Delgado, P. Elias, T. Gopalakrishna, M.R. Hamsik, M. Herrero, J. Kiesecker, E. Landis, L. Laestadius, S.M. Leavitt, S. Minnemeyer, S. Polasky, P. Potapov, F.E. Putz, J. Sanderman, M. Silvius, E. Wollenberg, and J. Fargione. 2017. Natural climate solutions. Proceedings of the National Academy of Sciences 114(44):11645-11650.

Guo, L.B., and R.M. Gifford. 2002. Soil carbon stocks and land use change: A meta analysis. Global Change Biology 8(4):345-360. 
Henderson, B.B., P.J. Gerber, T.E. Hilinski, A. Falcucci, D.S. Ojima, M. Salvatore, and R.T. Conant. 2015. Greenhouse gas mitigation potential of the world's grazing lands: Modeling soil carbon and nitrogen fluxes of mitigation practices. Agriculture, Ecosystems and Environment 207 (September 1, 2015):91-100.

Henderson, D.C. 2000. Carbon storage in grazed prairie grasslands of Alberta, Master's thesis, University of Alberta.

Herrick, J., O. Arnalds, B. Bestelmeyer, S. Brignezu, G. Han, M.V. Johnson, L. Montanarella, W. Pengue, and G. Toth. 2016. Unlocking the sustainable potential of land resources: Evaluation systems, strategies and tools. Nairobi, Kenya: United Nations Environment Programme, International Resource Panel.

Hufkens, K., T.F. Keenan, L.B. Flanagan, R.L. Scott, C.J. Bernacchi, E. Joo, N.A. Brunsell, J.Verfaillie, and A.D. Richardson. 2016. Productivity of North American grasslands is increased under future climate scenarios despite rising aridity. Nature Climate Change 6 (2016):710-714.

Ihori, T., I.C. Burke, and P.B. Hook. 1995. Nitrogen mineralization in native cultivated and abandoned fields in shortgrass steppe. Plant and Soil 171(2):203-208.

Ingram, L.J., P.D. Stahl, G.E. Schuman, J.S. Buyer, G.F. Vance, G.K. Ganjegunte, J.M. Welker, and J.D. Derner. 2008. Grazing impacts on soil carbon and microbial communities in a mixed-grass ecosystem. Soil Science Society of America Journal 72(4):939.

Irisarri, J.G., J.D. Derner, J.P. Ritten, and D.E. Peck. 2019. Beef production and net revenue variability from grazing systems on semiarid grasslands of North America. Livestock Science 220 (February 1, 2019):93-99.

Lal, R. 2019. Conceptual basis of managing soil carbon: Inspired by nature and driven by science. Journal of Soil and Water Conservation 74(2):29A-34A, doi: 10.2489/jswc.74.2.29A.

Lark, T.J., J.M. Salmon, and H.K. Gibbs. 2015. Cropland expansion outpaces agricultural and biofuel policies in the United States. Environmental Research Letters 10(4):044003.

Manley, J.T., G.E. Schuman, J.D. Reeder, and R.H. Hart. 1995. Rangeland soil carbon and nitrogen responses to grazing. Journal of Soil and Water Conservation 50(3):294-298.

McSherry, M.E., and M.E. Ritchie. 2013. Effects of grazing on grassland soil carbon: A global review. Global Change Biology 19(5):1347-1357.

Milchunas, D.G., J.R. Forwood, and W.K. Lauenroth. 1994. Productivity of long-term grazing treatments in response to seasonal precipitation.
Rangeland Ecology and Management/Journal of Range Management Archives 47(2):133-139.

Milchunas, D.G., and W.K. Lauenroth. 1993. Quantitative effects of grazing on vegetation and soils over a global range of environments. Ecological Monographs 63(4):328-366.

Milchunas, D.G., and M.W.Vandever. 2013. Grazing effects on aboveground primary production and root biomass of early-seral, mid-seral, and undisturbed semiarid grassland. Journal of Arid Environments 92(May 1, 2013):81-88.

Minasny, B., B.P. Malone, A.B. McBratney, D.A. Angers, D. Arrouays, A. Chambers, V. Chaplot, Z.-S. Chen, K. Cheng, B.S. Das, D.J. Field, A. Gimona, C.B. Hedley, S.Y. Hong, B. Mandal, B.P. Marchant, M. Martin, B.G. McConkey, V.L. Mulder, S. O'Rourke, A.C. Richer-de-Forges, I. Odeh, J. Padarian, K. Paustian, G. Pan, L. Poggio, I. Savin, V. Stolbovoy, U. Stockmann, Y. Sulaeman, C.-C. Tsui, T.-G. Vågen, B. van Wesemael, and L. Winowiecki. 2017. Soil carbon 4 per mille. Geoderma 292(Supplement C):59-86.

Morgan, J.A., W. Parton, J.D. Derner, T.G. Gilmanov, and D.P. Smith. 2016. Importance of early season conditions and grazing on carbon dioxide fluxes in Colorado shortgrass steppe. Rangeland Ecology and Management 69(5):342-350.

Mueller, K.E., D.M. Blumenthal, E. Pendall, Y. Carrillo, F.A. Dijkstra, D.G. Williams, R.F. Follett, and J.A. Morgan. 2016. Impacts of warming and elevated $\mathrm{CO}_{2}$ on a semi-arid grassland are nonadditive, shift with precipitation, and reverse over time. Ecology Letters 19(8):956-966.

Nakicenovic, N., and R. Swart (eds.). 2000. Special Report on Emissions Scenarios:A Special Report of Working Group III of the Intergovernmental Panel on Climate Change. Cambridge, UK: Cambridge University Press. http://www.grida. no/climate/ipcc/emission/index.htm.

Reeder, J.D., G.E. Schuman, J.A. Morgan, and D.R. Lecain. 2004. Response of organic and inorganic carbon and nitrogen to long-term grazing of the shortgrass steppe. Environmental Management 33(4):485-495.

Reeves, M.C., K.E. Bagne, and J. Tanaka. 2017. Potential climate change impacts on four biophysical indicators of cattle production from western US Rangelands. Rangeland Ecology and Management 70(5):529-539.

Robles, M.D., and I.C. Burke. 1998. Soil organic matter recovery on Conservation Reserve Program rields in southeastern Wyoming. Soil Science Society of America Journal 62(3):725-730.

Roche, L.M., T.K. Schohr, J.D. Derner, M.N. Lubell, B.B. Cutts, E. Kachergis,V.T.Eviner, and K. W.Tate. 2015. Sustaining working rangelands: Insights from rancher decision making. Rangeland Ecology and Management 68(5):383-389.

Rosenstock, S.S., and C.Van Riper, III. 2001. Breeding bird responses to juniper woodland expansion. Journal of Range Management 54(3):226-232.

Schuman, G.E., H.H. Janzen, and J.E. Herrick. 2002. Soil carbon dynamics and potential carbon sequestration by rangelands. Environmental Pollution 116(3):391-396.

Schuman, G.E., J.D. Reeder, J.T. Manley, R.H. Hart, and W.A. Manley. 1999. Impact of grazing management on the carbon and nitrogen balance of a mixed-grass rangeland. Ecological Applications 9(1):65-71.

Teague, W.R., S. Apfelbaum, R. Lal, U.P. Kreuter, J. Rowntree,C.A.Davies, R.Conser,M.Rasmussen, J. Hatfield, T. Wang, F. Wang, and P. Byck. 2016. The role of ruminants in reducing agriculture's carbon footprint in North America. Journal of Soil and Water Conservation 71(2):156-164, doi: 10.2489/jswc.71.2.156.

Teague, W.R., S.L. Dowhower, S.A. Baker, N. Haile, P.B. DeLaune, and D.M. Conover. 2011. Grazing management impacts on vegetation, soil biota and soil chemical, physical and hydrological properties in tall grass prairie. Agriculture, Ecosystems, and Environment 141(3-4):310-322.

The Nature Conservancy. 2019. Sustainable Grazing Lands. https://www.nature.org/en-us/ what-we-do/our-priorities/provide-food-andwater-sustainably/food-and-water-stories/ sustainable-grazing-lands/.

Tietjen, B., D.R. Schlaepfer, J.B. Bradford, W.K. Lauenroth, S.A. Hall, M.C. Duniway, T. Hochstrasser, G. Jia, S.M. Munson, D.A. Pyke, and S.D. Wilson. 2017. Climate change-induced vegetation shifts lead to more ecological droughts despite projected rainfall increases in many global temperate drylands. Global Change Biology 23(7):2743-2754.

Trumbore, S. 2000. Age of soil organic matter and soil respiration: Radiocarbon constraints on belowground C dynamics. Ecological Applications 10(2):399-411.

USDA. 2018. Summary Report: 2015 National Resources Inventory. Washington, DC, and Ames, IA: USDA Natural Resources Conservation Service and Center for Survey Statistics and Methodology, Iowa State University.

Verified Carbon Standard. 2017. Methodology for Sustainable Grassland Management (SGM). https:// verra.org/methodology/vm0026-methodologyfor-sustainable-grassland-management-sgm-v1-0/.

Walsh, J., D. Wuebbles, K. Hayhoe, J. Kossin, K. Kunkel, G. Stephens, P. Thorne, R. Vose, M. Wehner, D.Willis, D. Anderson, S. Doney, R. Feely, 
P. Hennon, V. Kharin, T. Knutson, F. Landerer, T. Lenton, J. Kennedy, and R. Somerville. 2014. Our changing climate. In Climate Change Impacts in the United States: The Third National Climate Assessment, eds. J.M. Melillo, T.C. Richmond, and G.W. Yohe, 19-67. Washington, DC: US Global Change Research Program.

Walthall, C.L., J. Hatfield, P. Backlund, L. Lengnick, E. Marshall, M. Walsh, S. Adkins, M. Aillery, E.A. Ainsworth, C. Ammann, C.J. Anderson, I. Bartomeus, L.H. Baumgard, F. Booker, B. Bradley, D.M. Blumenthal, J. Bunce, K. Burkey, S. M. Dabney, J.A. Delgado, J. Dukes, A. Funk, K. Garrett, M. Glenn, D.A. Grantz, D. Goodrich, S. $\mathrm{Hu}$, R.C. Izaurralde, R.A.C. Jones, S.-H. Kim, A.D.B. Leaky, K. Lewers, T.L. Mader,A. McClung, J.A. Morgan, D.J. Muth, M. Nearing, D.M. Oosterhuis, and D. Ort. 2012. Climate Change and Agriculture in the United States: Effects and adaptation. USDA Technical Bulletin/ Washington, DC: USDA.

Wang, X., B.G. McConkey, A.J.VandenBygaart, J. Fan, A. Iwaasa, and M. Schellenberg. 2016. Grazing improves $\mathrm{C}$ and $\mathrm{N}$ cycling in the Northern Great Plains: A meta-analysis. Scientific Reports 6:33190, doi:10.1038/srep33190.

Wilmer, H., J.D. Derner, M.E. Fernández-Giménez, D.D. Briske, D.J. Augustine, and L.M. Porensky. 2018. Collaborative adaptive rangeland management fosters management-science partnerships. Rangeland Ecology and Management 71(5):646-657.

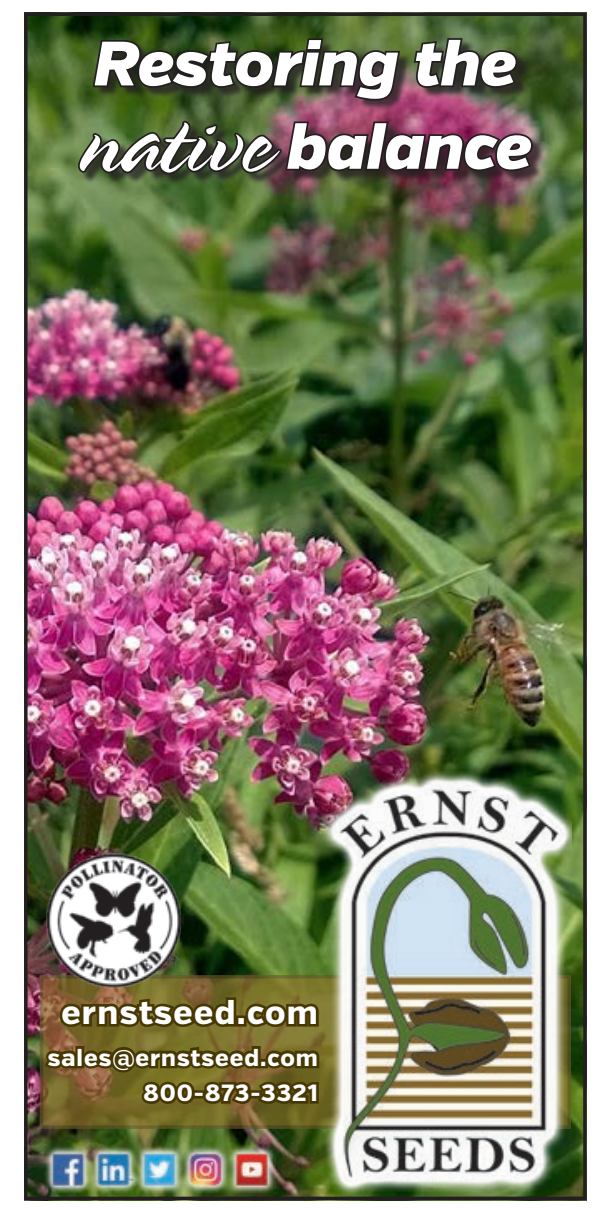
native bolince 